UDC 371.3:811

DOI 10.18485/primling.2015.16.10

\author{
Ljiljana Knežević \\ Prirodno-matematički fakultet, Univerzitet u Novom Sadu
}

\title{
LANGUAGE LEARNING STRATEGIES FOR ORAL PRESENTATION SKILLS: CROSS-CURRICULAR TEACHING PERSPECTIVES
}

\begin{abstract}
Summary: The paper explores the possibility of implementing language learning strategies taught in an ESP course into the task of preparing a presentation on a subject-specific topic in a biology course. The research participants were divided in two groups: the students who had a training in using language learning strategies (experimental group), and those who did not (control group). The research method implied a mixed approach of both quantitative and qualitative data: the assessment of students' presentations and the information gathered in semi-structured interviews conducted with the students after presenting their topics. The quantitative results show that the marks of the experimental group are significantly higher than those in the control group. The analysis of qualitative data suggests that the experimental group applied a larger number of learning strategies for preparing their biology course presentations and that many of the strategies were implemented from the English language course. In this way, the results of the study support the use of language learning strategies in cross-curricular teaching and learning.
\end{abstract}

Key words: cross-curricular teaching, language learning strategies, oral presentation skills, ESP

\section{Introduction}

Cross-curricular teaching is characterized by a synthesis of knowledge, skills and understandings from various subject areas (Savage 2011). This kind of teaching allows students to apply and transfer knowledge and skills from one subject to another and as such can create a more meaningful and challenging learning experience for them. It is also seen as a way to support goals such as transfer of learning, teaching students to think and reason, and providing a curriculum more relevant to students (Marzano 1991; Perkins 1991). Teaching and learning languages for specific purposes integrates students' subject matter and language instruction and as such seems to be a very convenient area for applying cross-curricular approach. In their language classes students refer to issues and topics relevant for their field of study and in that way are invited to use the knowledge and principles acquired in their subject area. On the other hand, students are also able to apply what they learn in foreign language lessons to their major field of study, which makes their learning experience highly motivating. Discussing the objectives of teaching English for specific purposes (ESP), Basturkmen (2006) refers to revealing subject-specific language use, developing target perfor- 
mance competencies and developing strategic competence. As learning foreign languages implies the use of a number of strategies - skills, actions, thoughts and operations that the learner applies in order to complete a specific task successfully, the application of these strategies is referred to as strategic competence. Many of the important concepts, strategies, and skills taught in the language arts are "portable", i.e. transferred to other content areas (Perkins 1986). For example, strategies for monitoring comprehension can be directed to reading material in any content area. Similarly, strategies for preparing an oral presentation in academic setting imply a number of steps and operations that are identical regardless of the field of study or the language in which the presentation is to be given. The present paper describes a study that aimed at exploring the possibility of implementing language learning strategies taught in an ESP course into the task of preparing a presentation for a biology course. The presentation was given in students' $\mathrm{L} 1$ and was related to a subject-specific topic. The results of the study point to a great potential for employing language learning strategies in cross-curricular concept of teaching and learning.

\section{Cross-curricular teaching}

Cross-curricular teaching provides a meaningful way in which students can use knowledge learned in one context as a knowledge base in other contexts in and out of school (Collins, Brown, \& Newman 1989). It is often seen as a way to address some of the recurring problems in education, such as fragmentation and isolated skill instruction (Marzano 1991, Perkins 1991). The term usually refers to three types of approach to teaching and learning: fusion, i.e. using two or more subjects to teach one topic, or applying knowledge and skills from one subject to understand and perform tasks for another subject; multidisciplinary, i.e. teaching one topic through different subjects; interdisciplinary, i.e. transferring knowledge from one subject to another. Although it may appear demanding for teachers in terms of requiring a lot of time and effort in planning, organizing and preparing lessons, cross-curricular teaching has many of the benefits. First of all, it highly increases students' motivation for learning, as it enables students to see the value of what they are learning, i.e. what they have learned. In addition, students are able to see the interconnectedness of topics and issues they learn in individual subjects and at the same time are encouraged to employ higher level thinking and reasoning skills, such as induction, deduction, critical thinking etc. Considering all of the benefits stated above, we can say that cross-curricular teaching greatly improves the learning process, as it provides conditions for effective learning - great motivation, broader context of learning, interaction and active involvement of students. Finally, as stated by Savage (2011), cross-curricular teaching promotes students' cognitive, personal and social development in an integrated way and provides opportunities for teachers to collaborate and co-operate meaningfully and at the same time to become more innovative and imaginative in their teaching.

\section{Language learning strategies}

Language learning strategies represent conscious thoughts and actions that learners take in order to achieve a learning goal (Chamot 2004). Analyzing how language 
learners process the information and what activities they are involved in while learning a language, second language acquisition research has shed light on many skills, actions and thoughts that efficient language learners apply (Green and Oxford 1995, O'Maley and Chamot 1990, Vandergrift 1997). Many studies have shown that the use of strategic knowledge contributes to better learning outcomes (Carrell 1989, Cohen 1998, Gu and Johnson 1996, O'Maley and Chamot 1990). The research of this kind is helpful in/for designing methodological approaches that develop these strategies and thus make language learning successful.

Various classification systems of language learning strategies are found in the literature on second language acquisition. Strategies were first classified into those that directly affect specific learning tasks and those whose effect is indirect (for example, planning a task). Present classification systems are much more complex. O'Malley and Chamot (1990), for example, classify language learning strategies into cognitive, metacognitive and socio-affective. Cognitive strategies refer to various mental activities used in processing information and completing specific tasks, such as deduction, summarizing or inferencing. Metacognitive strategies represent operations and activities for regulating and controlling the learning process, for example planning, self-monitoring or self-evaluation. Socio-affective strategies refer to various modes of interacting with other students and native speakers as well as actions that can regulate emotions and attitudes towards L2 learning and its use in everyday situations.

One of general characteristics of language learning strategies is their transferability to new tasks and situations. Harris and Grenfell (2004) emphasize the importance of metacognitive dimension in transferring strategies to new situations. In order to apply the acquired strategies to new tasks, students should be aware of their role and importance and should be able to monitor and control their use. The transfer of acquired knowledge and skills to new tasks is one of the fundamental concepts in education and yet the research on the transfer of language learning strategies has been scarce (Chamot 2004). A few studies (Harris 2007, Harris and Grenfell 2004) have confirmed the existence of transfer between strategies taught in L1 classes to their use in L2 classroom. The transfer was more common among high attaining students in comparison to low attaining students. High attainers used more metacognitive strategies and were making more transfers.

The present paper addresses the question of transferability of language learning strategies from L2 to L1. It focuses on transferability of strategies for preparing and giving an oral presentation in an ESP class to giving a presentation in L1 in a biology course. As oral presentation represents an academic genre that is characterized by many universal features and as such can be regarded as an international genre (Mauranen 2007), it appeared very suitable for analyzing the transferability of strategies necessary for preparing and giving a presentation in two different contexts. The focus of the study was the transfer of two types of strategies-cognitive and metacognitive ones. Cognitive strategies seem to be relevant for many of the activities important for preparing a presentation, such as the selection of material and its organization, while metacognitive strategies, as it has been stated above, play an important role in making strategy transfer possible. The study relied on the taxonomy of language learning strategies proposed by O'Malley and Chamot (1990). 


\section{Study design}

\subsection{Participants}

The study was conducted with 40 students of biology studying at the University of Novi Sad. The participants were second-year students, aged 19 to 20 , and were attending the third semester of their study course. All of the participants applied for an oral presentation on a subject-specific topic within a zoology course they were attending at that time. The students had already had some experience in giving oral presentations: they all gave presentations as a part of their ESP course at university, but half of them (the experimental group) had a strategy training prior to their presentations, while the other group (the control group) had no training of that kind. The students had their ESP course in the second semester of their undergraduate course. The strategy training with the experimental group included short tasks that focused on four aspects of oral presentations: the content, the structural organization, the use of visuals and the presentation style. The activities focused on the use of cognitive and metacognitive strategies and they were organized in the form of short tasks following the CALLA model (Chamot 2005). The model included four stages of completing the tasks: preparation, when students were invited to think and suggest what kind of strategies would be suitable for completing specific tasks; presentation, the stage at which the teacher focused the students' attention on some additional strategies that would be helpful; practice, the stage when students completed specific tasks (for example, how they would organize the introduction of a presentation on a specific topic) and evaluation, the stage at which students discussed what strategies were helpful and why. This last stage was particularly important for developing students' metacognitive competence. As for the control group, they completed similar tasks to those that their experimental group peers had, but were not instructed on the use of strategies. It is also important to say that all of the participants voluntarily applied for both their English and zoology presentation. In this way many of the psychological factors that affect the quality of student presentations could be excluded.

\subsection{Research methodology}

Considering the context described above, the aim of the research was to explore the possibility of applying language learning strategies taught in the ESP course into the task of preparing a presentation in L1 for the students' zoology course. Referring to the literature on language learning strategies, the starting hypothesis was that the experimental group students would rely on the strategies they were taught in their ESP course and that metacognitive strategies would be dominant in that use.

As the aim of the research was to identify the mental processes that the participants used while preparing their zoology presentations, there was a need for including qualitative data in the research. Accordingly, mixed-method research combining both qualitative and quantitative data was used in this study. The qualitative data were obtained from semi-structured interviews and the analysis of students' notes for preparing zoology presentations, while quantitative data included the assessment of the presentations. The interviews were conducted with the participants after their zoology presentations and included two general questions:

- Describe the process of preparing your presentation;

- In what way was your ESP presentation helpful to you; 
As it is seen, the first question did not address the students' experience with English language presentations while the second question directly asked them to refer to that experience.

The analysis of the qualitative data included the identification of cognitive and metacognitive strategies in the participants' answers to the above questions. The identified strategies were classified into four segments, depending on what aspect of presentation they referred to - the presentation content, the structural organization, the use of visuals and the presentation style. The present paper discusses the results obtained for two of the categories: the presentation content and the structural organization.

The quantitative data analysis included the comparison of the marks that the two groups of students got for their presentations. For this purpose the Mann-Whitney U test was applied.

\section{Research results}

The results of the research are presented in two segments: the first segment refers to the qualitative findings and the second segment presents the quantitative results.

\subsection{Qualitative analysis results}

The qualitative data point to the use of cognitive and metacognitive strategies referring to the selection and organization of the information that were included in the presentations. The strategies are presented in the table below, according to their frequency.

\begin{tabular}{|l|l|}
\hline Control group & Experimental group \\
\hline 1. Resourcing & 1. Resourcing \\
\hline 2. Translating & 2. Elaboration \\
\hline 3. Note taking & 3. Note taking \\
\hline & 4. Translating \\
\hline
\end{tabular}

Table 1: The use of cognitive strategies for preparing and organizing the content of students' presentations

As it can be seen, the most frequently used strategy in both groups is resourcing, i.e. the use of various sources for gathering information. In describing how they chose the content of their presentations, all of the participants referred to this strategy. They all used their coursebook and the internet, and in some cases, additional books from the library. The experimental group, however, used broader scope of sources, as some of the students reported the use of their high school textbooks and the library of the Faculty of Agriculture. The control group students often combined this strategy with translation, since most of the material they found on the internet was in English. The students of the experimental group, however, less frequently reported the use of translation, although this activity was certainly present while they searched for information. These students more frequently reported the use of elaboration with resourcing, as many of them made associations and tried to link new information with previously acquired knowledge, such as general zoology course from the first semester, or high school knowledge. These students 
also combined note taking strategy with resourcing, as they used notes to make an outline of their presentation. The control group used this strategy as well, but none of the students referred to creating an outline.

The table two shows the frequency of metacognitive strategies used for choosing the content of presentations.

\begin{tabular}{|l|l|}
\hline Control group & Experimental group \\
\hline Selective attention -1 student & Selective attention \\
\hline & Identifying the purpose of the task \\
\hline
\end{tabular}

Table 2: The use of metacognitive strategies for preparing and organizing the content of students' presentations

As the table shows, the control group students did not use metacognitive strategies (with an exception of one student). The experimental group students, on the other hand, relied on two metacognitive strategies in selecting the information for their presentations. While doing this, many of them paid particular attention to selecting material that would be attractive for the audience, i.e. their peers. This strategy was particularly used for creating the introduction and conclusion of the presentations. Along with this strategy, the students thought about the purpose of their presentations while choosing the content for them. As they reported it in the interviews, they tried to include all the necessary information that would help the other students to understand the topic fully and prepare it for taking their exam.

To summarize, the qualitative results on the use of cognitive and metacognitive strategies in selecting the presentation content showed that the experimental group employed a larger scope of strategies. The data also showed that the control group did not rely on metacognitive strategies.

\subsection{Quantitative analysis results}

The quantitative data refer to the analysis of marks that the participants got for their zoology presentations. The assessment was performed by the zoology course professor and the marking system included the scale 1-5, with 5 representing the highest mark. There were four segments included in the assessment: relevant information, topic scope, clear main points and supporting facts, details and examples. For comparing the experimental and the control group marks, the Mann-Whitney U test was applied and statistical significance was set as at the level $p<0.05$. The following table presents the quantitative results:

\begin{tabular}{|l|l|l|}
\hline & Control group & Experimental group \\
\hline Relevant information & 5.00 & 5.00 \\
\hline The scope of the topic & 4.90 & 5.00 \\
\hline Clear main points & 4.55 & 5.00 \\
\hline Supporting details & 4.66 & 4.90 \\
\hline Overall mark & 4.78 & 4.98 \\
\hline Standard deviation & 0.49 & 0.13 \\
\hline Significance $(Z)$ & -2.520 & \\
\hline$p$ & 0.012 & \\
\hline
\end{tabular}

Table 3: The assessment of the presentation content 
The overall results suggest that both groups of participants generally had high marks regarding the content of their presentations. Nevertheless, certain differences between the two groups are observable. The overall mark and standard deviation of the experimental group suggest that these students completely fulfilled the professor's criteria in respect to the four segments of the presentation content. The situation is different regarding the control group. The overall mark is lower and there is a significant difference at the level $\mathrm{p}<0.01$ between the two groups. Standard deviation suggests that there are variations in the marks, i.e. the quality of the presentation content in the control group varies. The lowest marks are recorded for expressing clear main points, suggesting that this was the most difficult task for the control group students.

\section{Discussion}

Analyzing the presented results, the following conclusion can be made: the qualitative results showed that the experimental group students used a larger scope of cognitive and metacognitive strategies, while the quantitative results showed that these students obtained higher marks in comparison with their peers in the control group. The results imply that the use of strategies contributed to better completion of the task, in this case, the selection and organization of the presentation content. The results are in line with literature data, as many of the studies have reported that wider scope of used strategies resulted in better completion of the language task (Cohen 1998, Gu and Johnson 1996, O’Maley and Chamot 1990).

With reference to the aim of this study, i.e. the possibility of applying the strategies taught in the foreign language course to the completion of a similar task in L1, it can be said that the three strategies detected only in the experimental group (elaboration, selective attention and identifying the purpose of the task) are actually the strategies that these students were instructed to use while attending their ESP course. Elaboration, i.e. making associations and connections with background knowledge, was a strategy that students were encouraged to apply in many segments, such as selecting the topic and the content, organizing information and presenting them in an appropriate order. It was often combined with the other two strategies, selective attention and identification of the purpose of the task. The students were asked to analyze if the information included in certain parts of their presentations (short tasks that they were given, such as to develop introduction or conclusion, or define main points in relation to a specific topic) would attract the attention of the audience and correspond to their background knowledge. It is important to point out that the control group did not make use of any metacognitive strategies. These findings can be brought into connection with the results reported by Harris (2007) and Harris and Grenfell (2004) who concluded that metacognitive dimension had a crucial role in transferring language learning strategies to new tasks and situations.

The interpretation of the quantitative results also points to the fact that the experimental group students transferred some of the learning strategies from their English to their biology course. These results showed that the lowest marks were recorded in the segment of providing clear main points of the presentation. Identification of the central idea and main points of the presentation was a part of the training conducted with the 
experimental group. This segment was developed by the strategies such as note taking with the aim of preparing the outline, elaboration, selective attention and identification of the purpose of the presentation. These are precisely the strategies that, as the qualitative data showed, the experimental group mostly relied on. The lower marks recorded in this segment can be brought into connection with the absence of these strategies among the control group students. In this way, we can say that the quantitative results support the findings of the qualitative data analysis.

\section{Pedagogical implications}

The results of the present study point to several pedagogical implications. First of all, it can be concluded that cognitive and metacognitive strategies can significantly improve oral presentation skills and therefore should be implemented in language and communication classes that aim at developing this skill. Furthermore, the results of the study suggest that cognitive and metacognitive language learning strategies can be employed not only in language classes but also in other subjects, such as biology, in completing certain academic tasks that are similar across disciplines. In this particular case, the task was how to prepare an oral presentation, but the use of language strategies can also refer to some other activities and language skills, such as writing a summary, listening to a lecture and taking notes, or critical reading. In order to apply this cross curricular concept of teaching, frequent communication and cooperation between language teachers and subject specialists is needed. Additionally, modification of present curricula would be necessary in order to harmonize the teaching activities and learning outcomes of various subjects and create conditions suitable for cross curricular teaching and learning.

\section{References}

Basturkmen, H. (2006). Ideas and options in English for specific purposes. New York: Lawrence Erlbaum Associates.

Carrell, P.L. (1989). Metacognitive awareness and second language reading. The Modern Language Journal, 73/2:121-134.

Chamot, A. U. (2004). Issues in language learning strategy research and teaching. Electronic Journal of Foreign Language Teaching, 1/1:14-26.

Chamot, A. U. (2005). Language learning strategy instruction: Current issues and research. Annual Review of Applied Linguistics, 25:112-115.

Cohen, A. (1998). Strategies in learning and using a second language. London: Longman.

Collins, A., Brown, J.S., and S.E. Newman, (1989). Cognitive apprenticeship: Teaching the crafts of reading, writing, and mathematics. In: Knowing, learning, and instruction: Essays in honor of Robert Glaser (L. B. Resnick, ed.), Hillsdale, NJ, Lawrence Erlbaum Associates, 453-494.

Green, J.M: and R. Oxford (1995). A closer look at learning strategies, L2 proficiency and gender. TESOL Quarterly, 29/2:261-297.

$\mathrm{Gu}$, Y. and R.K. Johnson (1996). Vocabulary Learning Strategies and Language Learning Outcomes. Language Learning, 46/4:643-679.

Harris, V. (2007). Language learning strategies across the curriculum: Government policy and school practice, available at http://www.leeds.ac.uk/educol/documents/160889.htm. 
Harris, V. and M. Grenfell (2004). Language learning strategies: a case for cross-curricular collaboration. Language Awareness, 13/2:116-130.

Mauranen, A. (2007). Discourse reflexivity and international speakers-how is it used in English as a lingua franca? Jezik in slovstvo, 52/3-4:1-19.

O'Malley, J.M. and Chamot, A.U. (1990) Learning Strategies in Second Language Acquisition, Cambridge: CUP.

Savage, J. (2011). Cross-curriculum teaching and learning in the secondary school. Routledge: Abingdon.

Marzano, R. J. (1991). Fostering thinking across the curriculum through knowledge restructuring. Journal of Reading, 34/7: 518-525.

Perkins, D.N. (1986). Knowledge as design. Hillsdale, NJ: Lawrence Erlbaum Associates.

Perkins, D.N. (1991). Educating for insight. Educational Leadership, 49/2:4-8.

Vandergrift, (2003). The comprehension strategies of second language (French) listeners: A descriptive study. Foreign Language Annals, 30/3:387-409.

\section{Ljiljana Knežević}

\section{STRATEGIJE ZA UČENJE JEZIKA U FUNKCIJI RAZVIJANJA \\ VEŠTINE USMENOG IZLAGANJA: PERSPEKTIVE ZA ORGANIZOVANJE INTERDISCIPLINARNE NASTAVE}

Sažetak: Interdisciplinarna nastava podrazumeva sintezu znanja, sposobnosti i veština iz različitih predmeta. Učenje stranog jezika, pak, podrazumeva upotrebu određenih strategija veština, operacija i aktivnosti koje učeniku omogućavaju da što uspešnije završi određeni zadatak. Ovaj rad ispituje mogućnost implementiranja strategija za pripremu usmenog izlaganja razvijanih u okviru nastave engleskog jezika struke na izlaganje u okviru jednog stručnog predmeta za studente biologije. U istraživanju su učestvovale dve grupe studenata: eksperimentalna grupa sa kojom su uvežbavane kognitivne i metakognitivne strategije za usmeno izlaganje u okviru nastave engleskog jezika i kontrolna grupa, s kojom te strategije nisu uvežbavane. Cilj je bio utvrditi da li će se repertoar strategija koje su studenti koristili u narednom izlaganju u okviru stručnog predmeta razlikovati između eksperimentalne i kontrolne grupe i da li će studenti eksperimentalne grupe koristiti strategije koje su sa njima prethodno razvijane u nastavi stranog jezika. Kvantitativni rezultati govore da su studenti eksperimentalne grupe pokazali bolji kvalitet izlaganju u odnosu na kolege iz kontrolne grupe, dok je analizom kvalitativnih podataka, transkripata intervjua $\mathrm{i}$ beležaka studenata, utvrđeno da je eksperimentalna grupa koristila širi repertoar strategija i da je većina njih bila identična strategijama koje su sa ovim studentima razvijane u nastavi jezika. Ovim je potvrđena mogućnost kombinovanja elemenata nastave jezika sa određenim zadacima u okviru drugih predmeta, u ovom slučaju biologije, čime se otvara mogućnost organizovanja interdisciplinarnog pristupa nastavi.

Ključne reči: interdisciplinarna nastava, strategije za učenje stranog jezika, usmeno izlaganje, nastava engleskog kao jezika struke 